\title{
Characterization and genetic variability of coat protein genes of Apple chlorotic leaf spot virus isolates from southern Brazil
}

\author{
Osmar Nickel $^{1}$ (D) - Fabio N. Silva ${ }^{2}$ Thor V. M. Fajardo ${ }^{1}$ • Eduardo S. Gorayeb ${ }^{2}$
}

Received: 12 May 2017 / Accepted: 10 October 2017 /Published online: 13 November 2017

(C) Sociedade Brasileira de Fitopatologia 2017

\begin{abstract}
Apple chlorotic leaf spot virus (ACLSV) infects temperate rosaceous fruit trees worldwide and causes a wide range of diseases that are economically highly damaging. This study was carried out to analyze genetic variability of regional ACLSV isolates and compare it with ACLSV isolates from other parts of the world. Nineteen amplicons of ACLSV, corresponding to the coat protein $(\mathrm{CP})$ gene of isolates from apple, plum, and nectarine, from two states in southern Brazil, have been analyzed for genetic variation and compared phylogenetically among themselves and with other sequences available in GenBank. Sequences identities among complete $\mathrm{CP}$ genes of these isolates ranged from 87.5 to $100 \%$ and 92.2 to $100 \%$ at the nucleotide (nt) and the deduced amino acid (daa) levels, respectively. In the comparison with isolates from Asia, Europe and North America, identities were 68.4 to $100 \%$ and 72.5 to $100 \%$ at $\mathrm{nt}$ and daa levels, respectively. Phylogenetic trees based on nucleotide sequences showed that these isolates grouped into two clusters, cluster 1 containing apple isolates and cluster 2 comprising apple, plum and nectarine isolates. Most Brazilian isolates showed conserved signatures $\left(\mathrm{Ser}^{40}, \mathrm{Leu}^{59}, \mathrm{Tyr}^{75}, \mathrm{Thr}^{130}\right.$ and $\left.\mathrm{Leu}^{184}\right)$ in their CPs, which place them with type B6 isolates. However, some
\end{abstract}

Section Editor: Jorge Rezende

Electronic supplementary material The online version of this article (https://doi.org/10.1007/s40858-017-0197-6) contains supplementary material, which is available to authorized users.

Osmar Nickel

osmar.nickel@embrapa.br

Embrapa Uva e Vinho, Bento Gonçalves, RS 95701-008, Brazil

2 Programa de Pós-graduação em Produção Vegetal, Centro de Ciências Agroveterinárias, Universidade do Estado de Santa Catarina, Lages, SC 88520-000, Brazil
Brazilian isolates were found to be variants of type B6. These analyzes indicated that Brazilian isolates had lower genetic variability compared to isolates from China, India and Japan and that the CP genes were under negative selection. The greatest diversity of nucleotides was observed in the central portion of the $\mathrm{CP}$ gene, represented predominantly by synonymous substitutions. One natural recombinant was detected among ACLSV isolates from Brazil.

Keywords ACLSV · Molecular characterization . Variability $\cdot$ Phylogeny $\cdot$ Recombination $\cdot$ Selection

\section{Introduction}

Apple chlorotic leaf spot virus (ACLSV) occurs worldwide in several fruit tree species, including apple, pear, quince, cherry, peach, plum, apricot and almond. Although latent in most commercial varieties, it causes a wide range of disorders. In sensitive cultivars of Malus, symptoms may include asymmetric leaf distortion, leaf drop, chlorotic leaf spots, ring and line patterns on foliage, stunting, bark necrosis and xylem pitting. In sensitive cultivars of Prunus, symptoms include graft incompatibility, necrosis and early decline of peach, plum pseudopox and internal necrosis of fruits, premature fruit fall, cracking and splitting of bark. Usually, severity of symptoms is a function of a viral strain's virulence, the plant species/ variety and the presence of mixed infections (Németh 1986; Jelkmann and Kunze 1995; Hadidi and Barba 2011). Incidence of latent infections in apple may reduce quality and yield of crop in nurseries and orchards up to $30 \%$ (Cembali et al. 2003). In southern Brazil, the virus is generally associated with scion-rootstock incompatibilities and decline of apple plants grafted on Maruba kaido (Malus prunifolia var. ringo) rootstocks (Nickel et al. 2001), most commonly in 
mixed infection with other latent viruses, a disfunction similar to apple topworking disease (Yanase et al. 1990). Heavy economic losses have occurred as a consequence of the common use of this highly virus-sensitive rootstock in the main apple producing areas.

ACLSV, the type species of the genus Trichovirus, family Betaflexiviridae, possesses filamentous, flexuous particles of 680-780 $\times 12 \mathrm{~nm}$, containing a single-stranded, positive sense RNA, about $7.5 \mathrm{~kb}$ nt in length (German et al. 1990; Yaegashi et al. 2011), excluding the polyadenylated tail at its $3^{\prime}$ end. The virus genome contains three overlapping open reading frames (ORFs). ORF 3 encodes the coat protein (CP) of $21.5 \mathrm{kDa}$ (Sato et al. 1993; Yoshikawa 2001). Studies on the characterization of genomic regions as well as the determination of genetic variability are important for understanding how viruses evolve, for the prediction of epidemics, for recommending control measures and for the development of reliable tools for diagnosis. There are no studies using the descriptors of genetic variability of ACLSV isolates. The few studies available in the literature assess local/regional populations for nucleotide and amino acid variation based on sequence comparisons and phylogeny (Rana et al. 2010; Gadiou et al. 2010). The N-terminal region of the ACLSV CP gene is considered to be among the most variable regions of ACLSV (German-Retana et al. 1997; Gadiou et al. 2010).

We undertook an analysis of genetic variability of the $\mathrm{CP}$ genes of Brazilian ACLSV isolates from apples, plum and nectarine in order to increase knowledge on their variability and qualify the support for diagnosis, molecular characterization and disease control.

\section{Material and methods}

\section{Plant material, virus isolates, nucleic acid extraction, RT-PCR, cloning and sequencing}

Apple production in Brazil is concentrated in hubs of high altitude (817 to $1360 \mathrm{~m}$ ) in three southern states, Rio Grande do Sul (RS) (Vacaria, Latitude 28 $50^{\prime} 83^{\prime \prime}$ S, Longitude 50 $94^{\prime}$

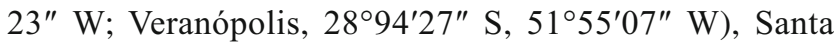
Catarina (SC) (Caçador, 26 $77^{\circ} 65^{\prime \prime} \mathrm{S}, 51^{\circ} 01^{\prime} 25^{\prime \prime} \mathrm{W}$; São Joaquim, 28 $29^{\prime} 25^{\prime \prime} \mathrm{S}, 4^{\circ} 93^{\prime} 76^{\prime \prime} \mathrm{W}$ ) and Paraná (PR),

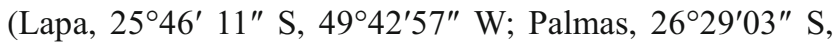
$\left.51^{\circ} 59^{\prime} 26^{\prime \prime} \mathrm{W}\right)$.

Nineteen different plant samples were collected in commercial orchards and research stations in SC and RS. Data on the characterized regional ACLSV isolates, GenBank accession numbers and host plants used in this study are listed in Table 1. Total nucleic acids were extracted from bark scrapings and young leaves. Samples were powdered in liquid nitrogen, macerated in the presence of grinding buffer $(4 \mathrm{M}$ guanidine hydrochloride, $0.2 \mathrm{M} \mathrm{NaOAc} \mathrm{pH} 5.2,25 \mathrm{mM}$
EDTA pH 8.0, 1.0 M KOAc and 2.5\% $w / v$ PVP-40) (Mackenzie et al. 1997) and adsorbed to silica particles (Rott and Jelkmann 2001). First strand cDNA synthesis reactions were carried out with Moloney murine leukemia virus reverse transcriptase (Invitrogen, $200 \mathrm{U} / \mu \mathrm{l}$ ), using an oligo-dT primer or reverse primer CL7365r (5'CTAAATGCAAAGAT CAGTCGAC 3'). PCR thermocycling (PTC100, MJ Research Inc.) was carried out under conditions described previously (Silva et al. 2008), using primers CL7365r and CL6784s (5' ATGGCAGCAGTTCTGAATTTG 3').

Amplified bands of the expected size were analyzed in agarose gels, purified using the Wizard SV Gel and PCR Clean Up System (Promega), and ligated into the cloning vector pGEM-T Easy (Promega) following the manufacturer's instructions. Ligation reactions were used to transform strain DH $5 \alpha$ of Escherichia coli cells by thermal shock at $42^{\circ} \mathrm{C}$, for $90 \mathrm{~s}$. Selected recombinant clones were cultivated in LB medium containing $100 \mu \mathrm{g} / \mathrm{ml}$ ampicillin (Russel and Sambrook 2001), purified using the Wizard Plus SV Miniprep DNA Purification System (Promega) and sequenced by the Sanger method (Sanger and Coulson 1975). Sequencing was carried out at Embrapa Recursos Genéticos e Biotecnologia (Brasília, DF).

\section{Nucleotide alignments and phylogenetic relationships}

Multiple nucleotide sequence alignments were performed using the Muscle algorithm in MEGA 6.0 (Tamura et al. 2013). Phylogenetic relationships were determined using the neighbor joining method implemented in MEGA 6.0 using the Kimura 2-parameter nucleotide substitution model with discrete gamma distribution $(\mathrm{G})$ and bootstrap support from 2000 replicates.

\section{Coat protein genetic variability, recombination and selection analyses}

Datasets for analyses of genetic variability were constructed with at least 10 isolates (Brazil, China, India and Japan). An additional, "world" dataset comprising isolates from Brazil (19), China (126), France (2), Germany (1), India (30), Japan (10) Latvia (12 clones from the same plant), Poland (1) Slovakia (2), Taiwan (2) and the United States (1) was included in the analyses (Table 1; Supplementary Table S1). Molecular variability descriptors [total number of segregating sites (S), number of nucleotide differences between sequences $(\mathrm{K})$, nucleotide diversity $(\pi)$, haplotype number $(\mathrm{H})$, haplotype diversity $(\mathrm{Hd})$ and Watterson's estimator for the population-scaled mutation rate] were estimated using DnaSP software v. 5.10 (Rozas et al. 2003). The mean pairwise number of nucleotide differences per site $(\pi)$ was calculated using a sliding window of 100 bases, with a step size of 25 bases across the ACLSV CP coding region. The CP 
Table 1 Data on full coat protein gene sequences of Brazilian isolates of Apple chlorotic leaf spot virus characterized in this study

\begin{tabular}{|c|c|c|c|c|}
\hline Host/cultivar & Collection site (Municipality/ state & Host & Isolate name & Genbank accession number \\
\hline Malus domestica cv. unknown & Epagria ${ }^{\text {a }}$, São Joaquim, SC & Apple & BR1 & EF138602 \\
\hline M. domestica cv. Fuji & Orchard, São Joaquim, SC & Apple & M220 & KT183386 \\
\hline M. domestica cv. Macfree & Epagri, Caçador, SC & Apple & M283 & KX668476 \\
\hline M. domestica cv. Nova Easygrow & Epagri, Caçador, SC & Apple & M281 & KX668477 \\
\hline M. domestica cv. Fuji & Orchard, São Joaquim, SC & Apple & M222 & KX668478 \\
\hline M. domestica cv. Fuji & Orchard, São Joaquim, SC & Apple & M228 & KX668479 \\
\hline M. domestica cv. Fuji & Orchard, São Joaquim, SC & Apple & M230 & KX668480 \\
\hline M. domestica cv. Fuji & Orchard, São Joaquim, SC & Apple & M232 & KX668481 \\
\hline M. domestica cv. Fuji Select & Orchard, Vacaria, RS & Apple & M184 & KX668482 \\
\hline M. domestica cv. Fuji Suprema & Epagri, Caçador, SC & Apple & M267 & KX668483 \\
\hline Prunus persica var. nucipersica $\mathrm{cv}$. Armking & Orchard, Vacaria, RS & Nectarine & NBR2 & KX668484 \\
\hline M. domestica cv. Cripps Pink & Orchard, Vacaria, RS & Apple & M075 & KX668485 \\
\hline M. domestica cv. Fuji Mishima & Orchard, Vacaria, RS & Apple & M270 & KX668486 \\
\hline M. domestica cv. Fuji Precoce & Epagri, São Joaquim, SC & Apple & M210 & KX668487 \\
\hline M. domestica cv. Golden Delicious & Epagri, São Joaquim, SC & Apple & M177 & KY009917 \\
\hline M. domestica cv. Red Delicious & Epagri, São Joaquim, SC & Apple & M176 & KY009918 \\
\hline P. salicina cv. Polli Rosa & Fepagro $^{\mathrm{b}}$, Veranópolis, RS & Plum & PR1 & KY009919 \\
\hline M. domestica cv. Maxi Gala & Orchard, Vacaria, RS & Apple & MG8B & KY009920 \\
\hline M. domestica cv. Fuji Kiku & Orchard, Vacaria, RS & Apple & M266 & KY315922 \\
\hline
\end{tabular}

${ }^{\text {a }}$ Santa Catarina State Agricultural Research Agency, SC, Brazil;

${ }^{\mathrm{b}}$ Rio Grande do Sul State Agricultural Research Foundation, RS, Brazil

gene molecular variability of ACLSV was evaluated using five previously described datasets.

Site-specific selection pressures were analyzed using four algorithms, Single Likelihood Ancestor Counting (SLAC), Fixed Effects Likelihood (FEL), Random Effects Likelihood (REL) and Partitioning for Robust Inference of Selection (PARRIS), within the HyPhy software implemented in the Datamonkey server (www.datamonkey.org) with default conditions. The nucleotide substitution model of Hasegawa Kishino-Yano (HKY) was used for all datasets, except the Chinese dataset (Tamura-Nei model). To avoid the effect of recombination events on selection analysis, recombination analysis was performed using the program RDP v.4.77 (Martin et al. 2015) and the GARD method (available at the Datamonkey server). In recombination analysis using the program RDP, only recombination events detected by at least three of the methods available in the program were considered reliable.

\section{Results and discussion}

The genetic diversity of ACLSV isolates was studied by sequencing and aligning nt $\mathrm{CP}$ sequences of cDNA clones of 19 southern Brazilian isolates. All CP sequences contained 582 nucleotides (nt) and 193 deduced amino acid (daa) residues
(Table 1). The regions of highest genetic variation in the ACLSV CP appear to vary considerably. They have been observed in the N-terminal (German et al. 1990) and the middle portion of the CP gene (Rana et al. 2010; Chen et al. 2013). Nucleotide diversity $(\pi)$ was analyzed throughout the length of the coat protein gene of ACLSV (Fig. 1). The tendency for $\pi$ values was similar in the five datasets analyzed, differing only in the absolute values of $\pi$ (Fig. 1). The ACLSV CP showed the greatest nucleotide diversity at position 200, and showed lower nucleotide diversity close to its $5^{\prime}$-terminal region (position 75) in the five datasets analyzed (Fig. 1). It is also possible to observe a decrease in the $\pi$ value from position 425 towards the 3 '-terminal region. In this study, variability of amino acids (non-synonymous substitutions) was concentrated in the N-terminal and middle regions of the $\mathrm{CP}$ (amino acids 2 to 114), which accumulate 17 positions with aa variations, while the C-terminal ends were substantially less variable (two amino acid variations, at positions 122 and 188). This is similar to the report by Al Rwahnih et al. (2004), where variability (represented by non-synonymous substitutions) was high in the $\mathrm{N}$-terminal, with the $\mathrm{C}$ terminal being significantly less divergent. When we analyzed the isolates from different countries, including the Brazilian dataset, we verified the same pattern. Nucleotide differences at non-synonymous sites are concentrated in the $5^{\prime}$-terminal region (corresponding to the $\mathrm{N}$-terminal region of the protein) 
Fig. 1 Mean pairwise number of nucleotide differences per site (nucleotide diversity, $\pi$ ) calculated on a sliding window across the coat protein gene of Apple chlorotic leaf spot virus isolates

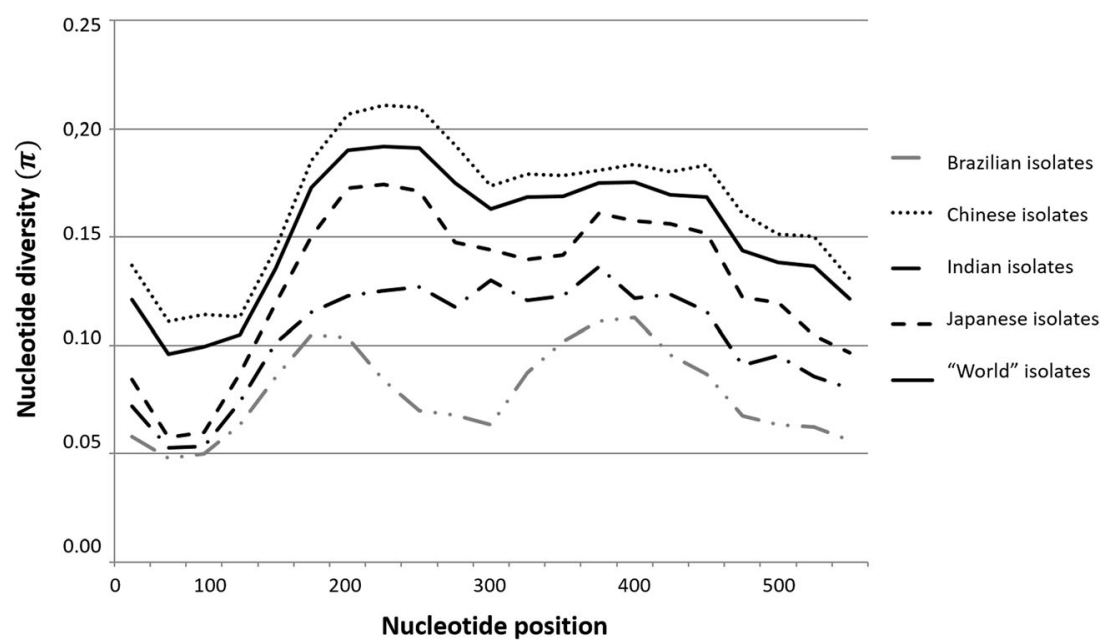

and in the central portion of the $\mathrm{CP}$ gene, although greater diversity of nucleotides relative to the synonymous sites was observed in the 3 '-terminal region (corresponding to the Cterminal region of the protein). Even though the 3 '-terminal region has the highest average value of $\pi$ (Fig. 2), these changes in the nucleotide sequence did not result in amino acid changes. These results suggest a strong negative selection acting on this region of the ACLSV CP.

Complete genome nucleotide sequences of 13 ACLSV isolates have been previously published, including isolates P205, A4, MO-5 from apple and B6 from apple and hawthorn (Sato et al. 1993; Yaegashi et al. 2007; Guo et al. 2016), P863 and PBM1 from plum (German et al. 1990; Jelkmann 1996) and Ta Tao 5, Z1 and Z3 from peach (Marini et al. 2008; Niu et al. 2012). Based on amino acid sequences, Japanese ACLSV CPs were reported to cluster into types P205 and B6, according to covariation of two combinations of five highly conserved aa sets: $\mathrm{Ala}^{40}, \mathrm{Val}^{59}, \mathrm{Phe}^{75}, \mathrm{Ser}^{130}$ and $\mathrm{Met}^{184}$ for isolates P205 and A4, and $\mathrm{Ser}^{40}$, $\mathrm{Leu}^{59}, \mathrm{Tyr}^{75}, \mathrm{Thr}^{130}$ and Leu ${ }^{184}$ for isolates B6 and MO-5 (Yaegashi et al. 2007). These authors also showed that co-variable aa positions 40 and 75 were critical for effective viral replication. Other multiple aa alignments showed another covariation in the ACLSV CP at position 79, among 55 Chinese apple ACLSV isolates (Chen et al. 2013). Brazilian isolates showed conserved signatures of type B6 isolates at positions 40, 59, 75, 130 and 184, that places them with type B6 isolates, except for isolates M220 (apple) and PR1 (plum), which appear to be variants of the type B6 isolates. Isolate M220 possesses one single P205-type amino acid residue change, $\mathrm{Leu}^{59}$ to $\mathrm{Val}^{59}$. Isolate PR1 appears as a newly recognized unique variation event, which shows a $\mathrm{Glu}^{79}$ to $\mathrm{Gly}^{79}$ variation, deviating from Chinese isolates (Chen et al. 2013) as well as from B6 type from Japan. Additionally, isolates M177 and M266 were uniquely co-variable, showing Glu to Lys at position 111. The functional role of these variations remains to be elucidated.
Phylogenetic analysis of the nineteen ACLSV sequences [18 ACLSV isolates from this study and one isolate (BR1) from a previous report (Silva et al. 2008)] and representative foreign isolates revealed their clustering into two groups based on nucleotide sequences (Fig. 3); daa sequence analysis

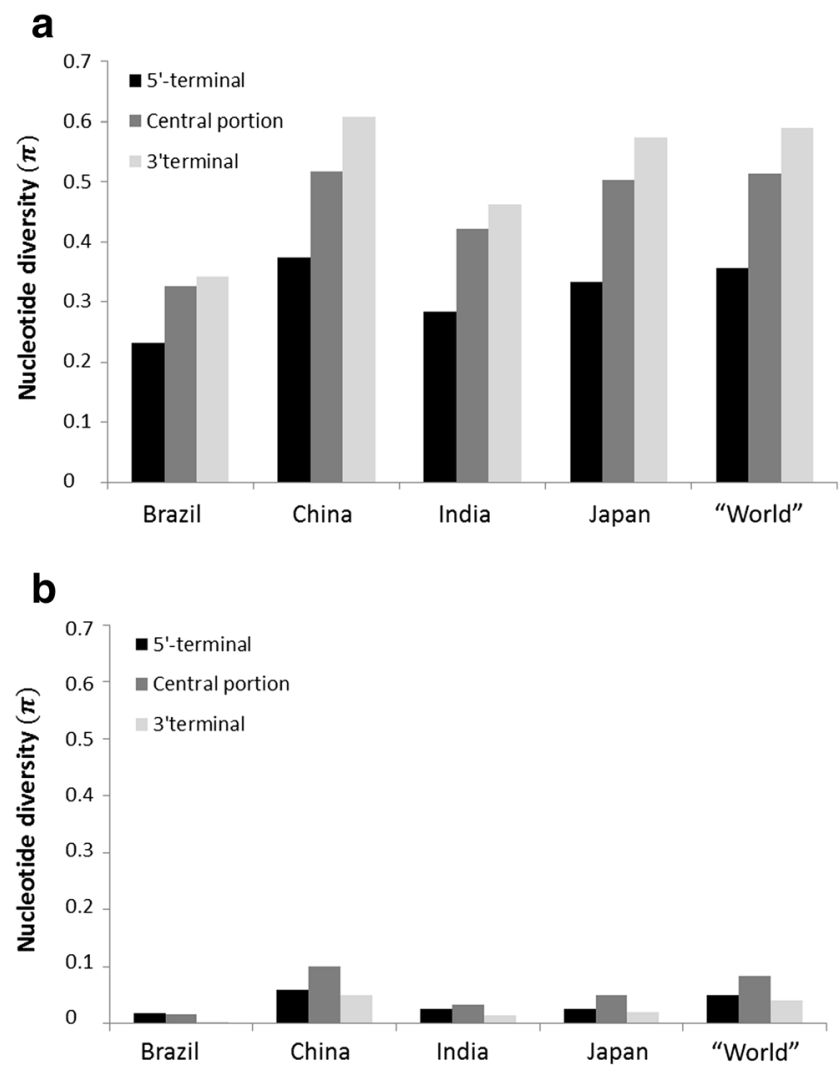

Fig. 2 Mean pairwise number of nucleotide differences per site (nucleotide diversity, $\pi$ ) at synonymous (a) and non-synonymous (b) sites calculated for three regions (5'-terminal, central and 3 '-terminal) of the coat protein gene of Apple chlorotic leaf spot virus isolates from Brazil, China, India, Japan and "world" 
Fig. 3 Phylogenetic tree based on the alignment of coat protein genes of Apple chlorotic leaf spot virus isolates from Brazil and representative foreign isolates. The tree was constructed by the neighbor joining method implemented in MEGA 6.0 program using the Kimura 2parameter nucleotide substitution model with discrete gamma distribution $(\mathrm{G})$ and bootstrap support of 2000 replications. Nodes with bootstrap values equal or higher than $80 \%$ are indicated by filled circles, and those with values lower than $80 \%$ and higher than $50 \%$ by empty circles. Names of isolates, location, access number and hosts are indicated. Grapevine berry inner necrosis virus (GBINV) was used as outgroup. Bar indicates number of substitutions per site.

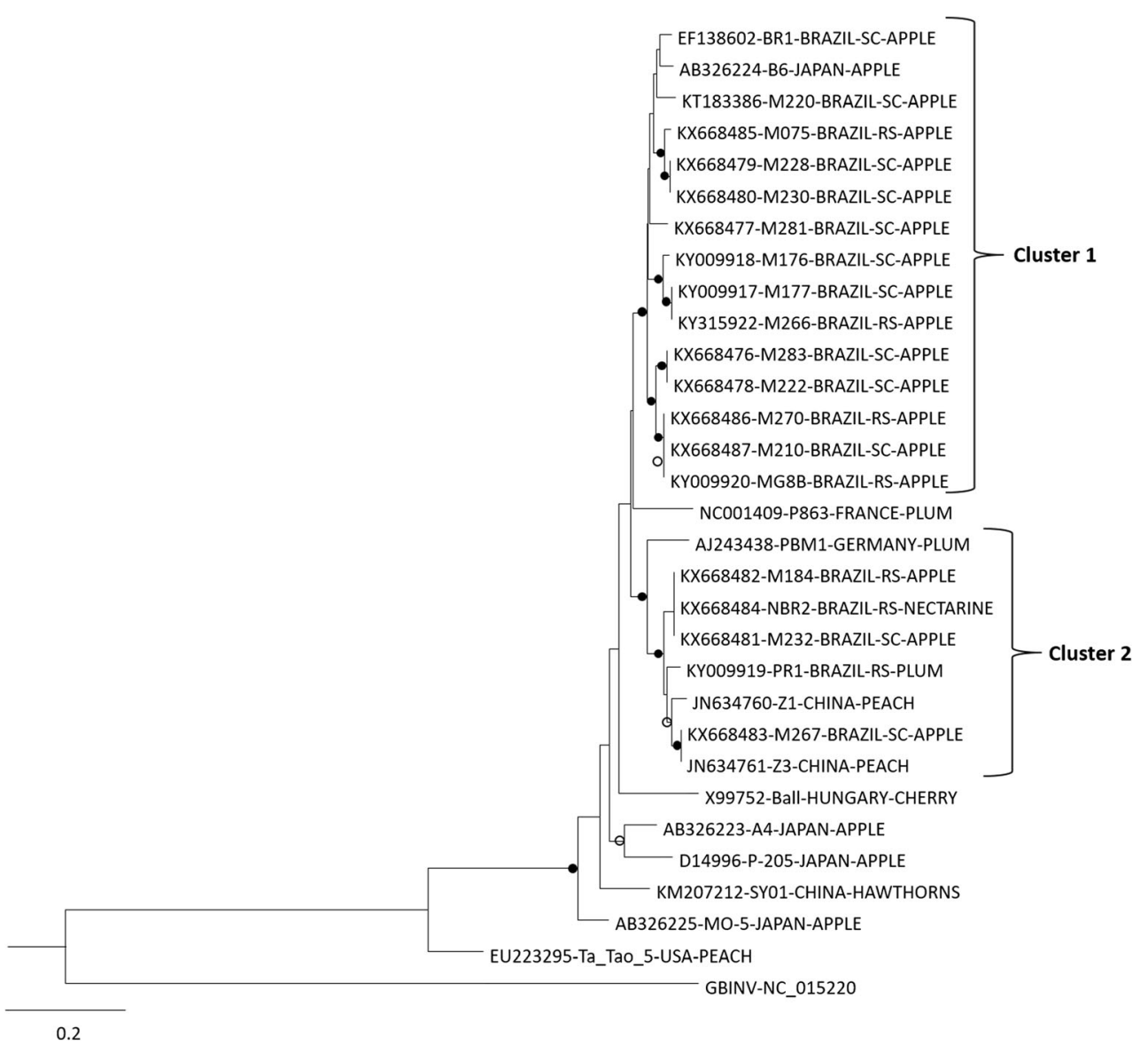

isolate PBM1 from plum (Fig. 3). Peach isolates have been previously classified into types Z1 and Ta Tao 5 (Niu et al. 2012).

To better characterize the genetic variability of the different isolates analyzed in this study, the descriptors of variability were determined (Table 2). Descriptors for the dataset consisting of Chinese, Japanese and "world" isolates indicated higher genetic variability than those from the

Table 2 Genetic variability of Apple chlorotic leaf spot virus coat protein genes from Brazil, China, India, Japan and "world" isolates

\begin{tabular}{lllllllll}
\hline ACLSV isolates $^{\mathrm{a}}$ & Number of isolates & $\mathrm{CP}$ lengh (nt) & $\mathrm{S}^{\mathrm{b}}$ & $\mathrm{K}^{\mathrm{c}}$ & $\pi^{\mathrm{d}}$ & $\mathrm{H}^{\mathrm{e}}$ & $\mathrm{Hd}^{\mathrm{f}}$ & $\theta-\mathrm{W}^{\mathrm{g}}$ \\
\hline Brazil & 19 & 582 & 130 & 44.754 & $0.07690 \pm 0.00542$ & 13 & 0.959 & 0.0639 \\
China & 126 & 582 & 330 & 95.971 & $0.16490 \pm 0.00796$ & 121 & 0.999 & 0.1048 \\
India & 30 & 582 & 162 & 60.421 & $0.10382 \pm 0.00391$ & 19 & 0.959 & 0.0703 \\
Japan & 10 & 582 & 173 & 74.711 & $0.12837 \pm 0.00974$ & 10 & 1.000 & 0.1051 \\
"World" & 206 & 582 & 350 & 88.442 & $0,15,196 \pm 0.00605$ & 172 & 0.997 & 0.1019 \\
\hline
\end{tabular}

${ }^{a}$ Five datasets of ACLSV sequences were analyzed: The datasets comprise isolates of Brazil, China, India, Japan and "world"

${ }^{\mathrm{b}}$ Total number of segregating sites

${ }^{\mathrm{c}}$ Mean number of nucleotide differences between sequences

${ }^{\mathrm{d}}$ Nucleotide diversity

${ }^{\mathrm{e}}$ Haplotype number

${ }^{\mathrm{f}}$ Haplotype diversity

${ }^{\mathrm{g}}$ Watterson's estimate of the population mutation rate based on the total number of segregating sites 
Table 3 Selection analysis of coat protein genes of Brazilian and foreign isolates of Apple chlorotic leaf spot virus

\begin{tabular}{|c|c|c|c|c|c|c|c|c|c|}
\hline \multirow[t]{2}{*}{ ACLSV isolates ${ }^{\mathrm{a}}$} & \multirow[t]{2}{*}{ Number of isolates } & \multirow[t]{2}{*}{$\mathrm{dN} / \mathrm{dS}$} & \multicolumn{2}{|c|}{ SLAC $^{\mathrm{b}}$} & \multicolumn{2}{|c|}{$\mathrm{FEL}^{\mathrm{c}}$} & \multicolumn{2}{|c|}{$\mathrm{REL}^{\mathrm{d}}$} & \multirow{2}{*}{$\begin{array}{l}\text { PARRIS } \\
\text { PS }\end{array}$} \\
\hline & & & $\mathrm{PS}^{\mathrm{f}}$ & NS & PS & NS & PS & NS & \\
\hline Brazil & 18 & 0.0559 & - & 33 & 1 & 64 & 1 & 95 & - \\
\hline China & 124 & 0.0775 & 1 & 150 & 1 & 154 & nd & nd & nd \\
\hline India & 29 & 0.0405 & - & 66 & - & 94 & - & 58 & - \\
\hline Japan & 10 & 0.0571 & - & 58 & 1 & 97 & 1 & 79 & - \\
\hline
\end{tabular}

${ }^{\text {a }}$ Recombinant ACLSV isolates M176 (KY009918 - Brazil), YC-WR-2 (KC404877 - China), YT-3-1 (KC404872

- China) and India 20 (AM498047 - India) were excluded from the selection analysis

$\mathrm{dN} / \mathrm{dS}$ - non-synonymous to synonymous substitution ratios

${ }^{\mathrm{b}}$ Single likelihood ancestor counting

${ }^{\mathrm{c}}$ Fixed effects likelihood

${ }^{\mathrm{d}}$ Random effects likelihood

${ }^{\mathrm{e}}$ Partitioning for robust inference of selection

${ }^{\mathrm{f}} \mathrm{PS} / \mathrm{NS}$ number of positive (PS) and negative (NS) selection sites; - , no site under selection; nd, not determined due to high number of sequences dataset comprising only Brazilian or Indian isolates (Table 2). The higher genetic variability is represented by a higher number of segregating sites $(\mathrm{S})$, nucleotide diversity $(\pi)$, haplotype number $(\mathrm{H})$ and haplotype diversity $(\mathrm{Hd})$ (Table 2). Nucleotide diversity $(\pi)$ in the Chinese dataset was the highest $(0.16490 \pm 0.00796)$ observed within the datasets analyzed. The dataset comprising ACLSV Brazilian isolates had a $\pi$ value of $0.07690 \pm 0.00542$, indicating lower genetic variability than the isolates from other countries. The $\pi$ value detected in ACLSV (for five datasets) is in accordance with $\pi$ values found in different viral species by several authors (Garcia-Arenal et al. 2001; Lima et al. 2013, 2017; Zanardo et al. 2014; Fajardo et al. 2017). The Watterson's estimator for the population-scaled mutation rate $(\theta-\mathrm{W})$ for Brazilian and Indian ACLSV isolates was in the order of $10^{-2}$, and for Chinese, Japanese and "world" isolates was in the order of $10^{-1}$ (Table 2), meaning that Chinese and Japanese isolates are more variable due to the greater number of mutations. The $\theta-\mathrm{W}$ values of $10^{-1}$ are lower when compared with other coding regions and other viral species described in the literature (Fajardo et al. 2017; Lima et al. 2013; Moura et al. 2018; Rocha et al. 2013; Zanardo et al. 2014).

In the selection analysis, datasets comprising Brazilian, Chinese, Indian and Japanese isolates were used, which represent a population of ACLSV. Since recombination events may affect the selection analysis, the Brazilian isolate M176, found to be a recombinant by three methods available in the RDP4 software, was excluded from sitespecific selection analysis (Supplementary Table S2). This is the first report on the occurrence of a recombinant ACLSV isolate from Brazil. Further recombination events were found in the CP genes of Chinese and Indian isolates (Rana et al. 2010; Chen et al. 2013), demonstrating that this mechanism contributes to the evolution of ACLSV CP genes. Recombinants from Chinese and Indian isolates were also excluded from the selection analyses. No recombination event was found in the dataset comprising Japanese isolates (data not shown).

The CP gene of ACLSV Brazilian isolates showed dN/dS ratios (non-synonymous/synonymous substitutions ratios) of 0.0559 (lower than 1.0), indicating negative selection (Table 3). Isolates from the other evaluated countries also presented $\mathrm{dN} / \mathrm{dS}$ ratios lower than 1 , with the $\mathrm{CP}$ of Chinese isolates presenting the highest value of $\mathrm{dN} / \mathrm{dS}$, featuring them as less restrictive to changes. At one site, codon 37, a positive selection in Brazilian and Chinese isolates was detected (Table 3 ). In this position, six Brazilian isolates (M075, M220, M222, M270, M281 and M283) possessed Thr; one isolate (M267) possessed Met; and the remaining contained Ile. The same amino acids were observed at position 37 of Chinese isolates; isolates LN-1-1, SMX-3-3 and TS-4-2 also showed Met at this position. In the Japanese dataset, position 60 was observed to be under positive selection with variation in aa Leu, Met, Gln, Ser, Thr and Val. The codon AUG in viral RNA sequences (corresponding to aa Met) at position 37 could indicate an internal ribosome entry site (IRES). IRES are able to mediate internal entry of the $40 \mathrm{~S}$ ribosomal subunit on viral messenger RNAs upstream of a translation initiation codon (Bonnal et al. 2003). If the first AUG is in an unfavorable context, $40 \mathrm{~S}$ subunits may bypass it and initiate RNA synthesis at downstream AUG codons (Ivanov et al. 1997; MartínezSalas et al. 2008). Although the AUG codon was found within the CP coding region of some isolates from Brazil, China and Japan, viral IRES Prediction System (Hong et al. 2013) did not find an IRES structure in the respective sequences in this study (data not shown). For Indian isolates, sites under positive selection were not detected (Table 3). The positive selection found at positions 37 and 60 may 
indicate an adaptive selection for these sites in the $\mathrm{CP}$ gene of Brazilian, Chinese and Japanese ACLSV isolates.

The number of sites under negative selection varies with the method employed and datasets used (Table 3; Supplementary Table 3). Selection pressures are important for expression of functional features of viral structures (Garcia-Arenal et al. 2001). Amino acids that are relevant for the assembly and stabilization of virus particles are conserved in tobamoviruses (Altschuh et al. 1987). Viral proteins are multifunctional and may be involved in other processes such as replication, cell-to-cell, and long distance movement and transmission of viruses (Garcia-Arenal et al. 2001). Accordingly, negative selection is predominant in the coding regions of viral proteins. The results presented on characteristics of CP genes of ACLSV are consistent with the fact that the viral structural genes are under negative selection and are constrained regions (Chare and Holmes 2004; Zanardo et al. 2014). To our knowledge, this is the first report on complete $\mathrm{CP}$ genetic variability and phylogenetic relationships of ACLSV isolates occurring in Malus and Prunus spp. in southern Brazil and the first detection of regional recombinant isolates and comparative analyzes with CP genes of ACLSV isolates from other apple growing regions.

Acknowledgements This work was financed by Embrapa project nr. 03.13.05.007. Authors thank Francisco J.L. Aragão (Embrapa Recursos Genéticos e Biotecnologia, Brasília, DF) for sequencing, Marcos F. Vanni for technical support, and $\mathrm{CNPq}$ for financial support.

\section{References}

Al Rwahnih M, Turturo C, Minafra A, Saldarelli P, Myrta A, Pallás V, Savino V (2004) Molecular variability of Apple chlorotic leaf spot virus in different hosts and geographical regions. Journal of Plant Pathology 86:117-122

Altschuh D, Lesk AM, Bloomer AC, Klug A (1987) Correlation of coordinated amino acid substitutions with function in viruses related to tobacco mosaic virus. Journal of Molecular Biology 193:693-707

Bonnal S, Schaeffer C, Creancier L, Clamens S, Moine H, Prats AC, Vagner S (2003) A single internal ribosome entry site containing a G quartet RNA structure drives fibroblast growth factor 2 gene expression at four alternative translation initiation codons. Journal of Biological Chemistry 278:39330-39336

Cembali T, Folwell RJ, Wandschneider P, Eastwell KC, Howell WE (2003) Economic implications of a virus prevention program in deciduous tree fruits in the USA. Crop Protection 22:1149-1156

Chare ER, Holmes EC (2004) Selection pressures in the capsid genes of plant RNA viruses reflect mode of transmission. Journal of General Virology 85:3149-3157

Chen S, Zhou Y, Ye T, Hao L, Guo L, Fan Z, Li S, Zhou T (2013) Genetic variation analysis of apple chlorotic leaf spot virus coat protein reveals a new phylogenetic type and two recombinants in China. Archives of Virology 159:1431-1438

Fajardo TVM, Silva FN, Eiras M, Nickel O (2017) High-throughput sequencing applied for the identification of viruses infecting grapevines in Brazil and genetic variability analysis. Tropical Plant Pathology 42:250-260

Gadiou S, Kundu JK, Paunovic S, Garcia-Diez P, Komorowska B, Gospodaryk A, Handa A, Massart S, Birisik N, Takur PD, Polischuk V (2010) Genetic diversity of flexiviruses infecting pome fruit trees. Journal of Plant Pathology 92:685-691

Garcia-Arenal F, Fraile A, Malpica JM (2001) Variability and genetic structure of plant virus populations. Annual Review of Phytopathology 39:157-186

German S, Delbos RP, Candresse T, Lanneau M, Dunez J (1990) Complete nucleotide sequence of the genome of a severe cherry isolate of Apple chlorotic leaf spot trichovirus (ACLSV). Archives of Virology 142:833-841

German-Retana S, Bergey B, Delbos RP, Candresse T, Dunez J (1997) Complete nucleotide sequence of the genome of a severe cherry isolate of apple chlorotic leaf spot trichovirus (ACLSV). Archives of Virology 142:833-841

Guo W, Zheng W, Wang M, Li X, Ma Y, Dai H (2016) Genome sequences of three apple chlorotic leaf spot virus isolates from hawthorns in China. PLoS One 11:e0161099

Hadidi A, Barba M (2011) Economic impact of pome fruit and stone fruit viruses and viroids. In: Hadidi A, Barba M, Candresse T, Jelkmann W (eds) Virus and virus-like diseases of pome and stone fruits. APS Press, St. Paul, pp 1-7

Hong JJ, TY W, Chang TY, Chen CY (2013) Viral IRES prediction system - a web server for prediction of the IRES secondary structure in silico. PLoS One 8:e79288

Ivanov PA, Karpova OV, Skulachev MV, Tomashevskaya OL, Rodionova NP, Dorokhov YL, Atabekov JG (1997) A tobamovirus genome that contains an internal ribosome entry site functional in vitro. Virology 232:32-43

Jelkmann W (1996) The nucleotide sequence of a strain of Apple chlorotic leaf spot virus (ACLSV) responsible for plum pseudo-pox and its relation to an apple and plum bark split strain. Phytopathology $86: 101$

Jelkmann W, Kunze L (1995) Plum pseudopox in German prune after infection with an isolate of Apple chlorotic leafspot virus causing plum line pattern. Acta Horticulturae 386:122-125

Lima ATM, Sobrinho RR, Gonzalez-Aguilera J, Rocha CS, Silva SJC, Xavier CAD, Silva FN, Duffy S, Zerbini FM (2013) Synonymous site variation due to recombination explains higher genetic variability in begomovirus populations infecting non-cultivated hosts. Journal of General Virology 94:418-431

Lima ATM, Silva JCF, Silva FN, Urquiza GPC, Silva FF, Seah YM, Mizubuti ESG, Duffy S, Zerbini FM (2017) The diversification of begomovirus populations is predominantly driven by mutational dynamics. Virus Evolution 3:vex005

Mackenzie DJ, Maclean MA, Ukerji S, Green M (1997) Improved RNA extraction from woody plants for the detection of viral pathogens by reverse transcription-polymerase chain reaction. Plant Disease 81 : $222-226$

Marini DB, Gibson PG, Scott SW (2008) The complete nucleotide sequence of an isolate of apple chlorotic leaf spot virus from peach [Prunus persica (L.) batch]. Archives of Virology 153:1003-1005

Martin DP, Murrell B, Golden M, Khoosal A, Muhire B (2015) RDP4: Detection and analysis of recombination patterns in virus genomes. Virus Evolution 1:vev003

Martínez-Salas E, Pacheco A, Serrano P, Fernandez N (2008) New insights into internal ribosome entry site elements relevant for viral gene expression. Journal of General Virology 89:611-626

Moura CJM, Fajardo TVM, Eiras M, Silva FN, Nickel O (2018) Molecular characterization of GSyV-1 and GLRaV-3 and prevalence of grapevine viruses in a grape-growing area. Scientia Agricola 75(1):43-51

Németh M (1986) Virus, mycoplasma and rickettsia diseases of fruit trees. Martinus Nijhoff Publ, Dordrecht 
Nickel O, Fajardo TVM, Jelkmann W, Kuhn GB (2001) Sequence analysis of the capsid protein gene of an isolate of Apple stem grooving virus, and its survey in southern Brazil. Fitopatologia Brasileira 26: 655-659

Niu F, Pan S, Wu Z, Jiang D, Li S (2012) Complete nucleotide sequences of the genomes of two isolates of apple chlorotic leaf spot virus from peach (Prunus persica) in China. Archives of Virology 157:783786

Rana T, Chandel V, Kumar Y, Ram R, Hallan V, Zaidi AA (2010) Molecular variability analyses of Apple chlorotic leaf spot virus capsid protein. Journal of Biosciences 35:605-615

Rocha CS, Castillo-Urquiza GP, Lima ATM, Silva FN, Xavier CAD, Hora-Junior BT, Beserra-Junior JEA, Malta AWO, Martin DP, Varsani A, Alfenas-Zerbini P, Mizubuti ESG, Zerbini FM (2013) Brazilian begomovirus populations are highly recombinant, rapidly evolving, and segregated based on geographical location. Journal of Virology 87:5784-5799

Rott ME, Jelkmann W (2001) Characterization and detection of several filamentous viruses of cherry: adaptation of an alternative cloning method (DOP-PCR), and modification of an RNA extraction protocol. European Journal of Plant Pathology 107:411-420

Rozas J, Sanchez-Delbarrio JC, Messeguer X, Rozas R (2003) DnaSP, DNA polymorphism analyses by the coalescent and other methods. Bioinformatics 19:2496-2497

Russel DW, Sambrook J (2001) Molecular cloning: a laboratory manual, 3rd edn. Cold Spring Harbor Laboratory Press, New York

Sanger F, Coulson AR (1975) A rapid method for determining sequences in DNA by primed synthesis with DNA polymerase. Journal of Molecular Biology 94:441-448
Sato K, Yoshikawa N, Takahashi T (1993) Complete nucleotide sequence of the genome of an apple isolate of Apple chlorotic leaf spot virus. Journal of General Virology 74:1927-1931

Silva FN, Nickel O, Fajardo TVM, Bogo A (2008) Indexação biológica múltipla e RT-PCR para detecção de vírus latentes em macieiras. Tropical Plant Pathology 33:157-161

Tamura K, Stecher G, Peterson D, Filipski A, Kumar S (2013) MEGA6: molecular evolutionary genetics analysis version 6.0. Molecular Biology and Evolution 30: 2725-2729

Yaegashi H, Isogai M, Tajima H, Sano T, Yoshikawa N (2007) Combinations of two amino acids (Ala ${ }^{40}$ and $\mathrm{Phe}^{75}$ or $\mathrm{Ser}^{40}$ and $\mathrm{Tyr}^{75}$ ) in the coat protein of apple chlorotic leaf spot virus are crucial for infectivity. Journal of General Virology 88:2611-2618

Yaegashi H, Yoshikawa N, Candresse T (2011) Apple chlorotic leaf spot virus in pome fruits. In: Hadidi A, Barba M, Candresse T, Jelkmann W (eds) Virus and virus-like diseases of pome and stone fruits. APS Press, St. Paul, pp 17-21

Yanase H, Mink GI, Sawamura K, Yamaguchi A (1990) Apple topworking disease. In: Jones AL, Aldwinckle HS (eds) Compendium of apple and pear diseases. APS Press, St. Paul, pp 74-75

Yoshikawa N (2001) Apple chlorotic leaf spot virus. Commonwealth Mycological Institute (CMI)/Association of Applied Biologists (AAB) Descriptions of Plant Viruses 386, no. 30 revised

Zanardo LG, Silva FN, Lima AT, Milanesi DF, Castilho-Urquiza GP, Almeida AM, Zerbini FM, Carvalho CM (2014) Molecular variability of cowpea mild mottle virus infecting soybean in Brazil. Archives of Virology 159:727-737 